\title{
Heavy Metals in Liver, Kidney, Brain and Muscle: Health Risk Assessment for Consumption of Edible parts of Birds from the Chahnimeh reservoirs Sistan (Iran)
}

Reza Dahmardeh Behrooz ( $\sim$ dahmardeh_behrooz@yahoo.com )

Enviromental

Joanna Burger

Rutgers University: Rutgers The State University of New Jersey

\section{Research Article}

Keywords: Heavy metals, Birds, Sistan, Health Risk Assessment

Posted Date: March 2nd, 2021

DOI: https://doi.org/10.21203/rs.3.rs-256665/v1

License: () (1) This work is licensed under a Creative Commons Attribution 4.0 International License. Read Full License 


\section{Abstract}

The concentrations of four heavy metals zinc $(\mathrm{Zn})$, lead $(\mathrm{Pb})$, nickel $(\mathrm{Ni})$ and cadmium $(\mathrm{Cd})$ were determined in liver, kidney, muscle and brain of nine species of birds from the Chahmimeh Sistan from Iran, to assess metal levels and the potential risk to birds, and to the people who eat them. Higher levels of all metals were found in the brain of waterfowl than in the tissues of other birds $(P<0.05)$. There were no significant gender differences in heavy metals in all tissue. Levels of $\mathrm{Pb}, \mathrm{Cd}, \mathrm{Ni}$ and $\mathrm{Zn}$ in the liver and kidney varied as a function of feeding habitats; the median levels were higher in invertebrate predators than fish predators and omnivorous species $(P<0.05)$. Short distance migrating birds had higher median levels of heavy metals in liver and kidney than long distance migrant birds $(P<0.05)$. Ni levels in liver and kidney tissues in $56 \%$ of birds were higher than the critical thresholds levels for effects in birds. Our data indicate that environmental exposure to metals were higher in the wintering populations of birds in the Chahnimeh of Sistan from Iran. Concentration $\mathrm{Zn}, \mathrm{Pb}$ and $\mathrm{Cd}$ in a small percentage of birds, and $56 \%$ nickel level in liver and 56\% kidney concentrations in birds, were above toxicity levels. Examination EDI, EWI and $\mathrm{HQ}$ of the edible tissues (kidney, Liver and muscle) of these birds showed that their consumption is a threat to the health of the people of the region.

\section{Introduction}

Aquatic environments accumulate pollutants from runoff and atmospheric deposition. While these areas are dynamic, they have a limited capacity to accept man-made waste without adverse effects on biota. With further technology advancement and the development of industries, the volume of waste imported into water areas will likely increase. Heavy metals are pollutants of concern due to their toxicity, persistence, and accumulation in the tissues of living organisms.

Generally, the main heavy metals of concern in the environment are from pesticides, chemical fertilizers, electroplating, preparation of paint, coal production, oil combustion, pigments, batteries, photovoltaic cells, greenhouse gas production processes, vehicles, synthetic plastic, extraction from foundry mines, leather product, urban waste incinerators and industrial waste (Kanwal et al. 2020). Besides heavy metals deriving from different industrial and agricultural sources, rocks and volcanoes are an additional source (Lucia et al. 2010). The increase of heavy metals in the biotic and abiotic environment are of great concern because of their adverse human health effects (Wu et al. 2016). Small quantities of heavy metals such as lead, cadmium and chromium, and high concentrations of essential elements such as copper and zinc, in living tissue tissues have caused major concerns due to their serious health effects in birds (Abbasi et al. 2015).

Birds are well suited for biomonitoring because their biology is well known, they have a relatively long lifespan and feed on different levels of the food chain depending on the species. Birds are exposed to environmental pollution because of their longevity and foods (wide range of food sources in terrestrial and aquatic food chains), and are therefore one of the best indicators for evaluating heavy metals (Abbasi et al., 2015, Burger and Gochfeld, 2016). Birds are exposed to environmental pollutants from direct contact with contaminated water and food. Studies show that heavy metal compounds accumulate in the organs of birds, especially waterfowl and other bird species that depend on rivers and other aquatic habitats to collect their food. High levels can be harmful and toxic to their reproduction and survival (Savinov et al. 2003). Also, birds are used as an indicator of environmental pollution on a local, regional and global scales (Burger and Gochfeld 2016). Examining levels in local species can be compared with those that migrate in (and therefore represent contamination over a larger geographical area)(Frederick et al. 1999).

The process of bioaccumulation of heavy metals in birds is very complex and under the influence of many factors, including biotic and abiotic factors, climate, geographical conditions, physicochemical differences, natural and mobility and bioavailability of metals. These factors also affect the anthropogenicy distributions, pollution in aquatic, air and soil environments around them (Aloupi et al. 2017). Behavioral factors such as migration, foraging methods or grit seeking, and position in the food chain influence exposure as well (Beyer et al. 1998; Burger et al. 2003; Peakall and Burger 2003). Metals are absorbed in the body, enter the blood circulation, and then exhibit different levels in living things or tissues, relation to on the reaction to lipids, solubility and transport in different specific cells (Burger et al. 2003). Distribution and concentration of metals in various organs and tissues are influenced by various characteristics of internal or host antibiotics such as body nutritional status, weight size, sex, homeostatic mechanisms of genetics, and interaction with nutrients or micronutrients reproduction contract (Honda et al. 1986; Burger et al. 2003; Peakall and Burger 2003).

Because of the key role liver and kidney play in detoxification processes, heavy metals such as $\mathrm{Cd}, \mathrm{Pb}, \mathrm{Ni}$ and $\mathrm{Hg}$, have been studied, and threat levels have most often been derived for these toxic metals (Kalisińska et al. 2010; Espin et al. 2016). Similarly, levels of lead are examined in bone or brain because of their accumulation over a lifetime, and the effect they have on the nervous system can be used for diagnostic purposes (Pain 1996; Kalisinska 2000).

In recent years, human activities as high agriculture, leakage of contaminated water to groundwater sources, drainage and hunting have posed a serious threat to wildlife (Angelidis and Albanis 1996; Hellenic Ornithological Society 2016). This anthropogenic pollution increased organic matter, nutrients, and heavy metals in water and sediment samples (de Luis et al. 2011; Rajaei et al. 2012; Sayadi et al. 2015; Bazrafshan et al. 2016) and fishes (Dahmardeh Behrooz et al. 2013; Ariyaee et al. 2015) from Chahnime, Iran. Some of the pollutants come from agricultural and industrial activities in Iran and Afghanistan that run off into the Helmand River that supplies water to Hamoun International Wetland and semi-wells (Dahmardeh Behrooz et al. 2013). The amount of heavy metal contamination in birds in this area has not been studied.

The objective of this study is to assess potential heavy metal pollution of birds wintering in the Chanimeh reservoirs of Sistan region in eastern Iran. We determined the levels of cadmium (Cd), lead $(\mathrm{Pb})$, nickel $(\mathrm{Ni})$ and zinc $(\mathrm{Zn})$ in brain, liver, kidney and muscle samples from nine species of birds in Chanimeh, in the Sistan region in easern Iran. We examined cadmium ( $\mathrm{Cd})$, lead ( $\mathrm{Pb})$, nickel $(\mathrm{Ni})$ and zinc ( $\mathrm{Zn}$ ) differences as a function of migration, sex, species, and feeding habits using liver, kidney, brain and muscle samples. We also compared levels to those published in the literature, and examined the risk of metals for endangered species of waterfowl in the Chanimeh of Sistan. Although sample sizes per species are low, this represents the first metals data of its kind from this region, and provides the first risk assessment for humans eating these birds. 


\section{Materials And Methods}

\subsection{Collection of samples}

Fifty individual birds of eight species, cormorant (Phalacrocorax carbo, $\mathrm{n}=6$ ), great crested grebe (Podiceps cristatus, $\mathrm{n}=10$ ), black-winged stilt (Himantopus himantou, $\mathrm{n}=10$ ), moorhen (Gallinula chloropus, $\mathrm{n}=6$ ), shoveler (Anas clypeata, $\mathrm{n}=8$ ), marsh sandpiper (Tringa stagnatilis, $\mathrm{n}=6$ ), eurasian spoonbill (Platalea leucorodia, $\mathrm{n}=2$ ) and northern lapwing (Vanellus vanellus $\mathrm{n}=2$ ) were purchased from Chanimeh of Sistan fishermen during February and March in 2019. Birds were weighed and stored in plastic bags that were previously cleaned with acetone and water. Samples were kept at $-20^{\circ} \mathrm{C}$ until dissection and analysis.

\subsection{Analytical procedure}

Birds were thawed, and liver, kidney, brain and a pectoral muscles tissues were collected. A 1 to $3 \mathrm{~g}$ wet weight samples were placed into Erlenmeyer flasks with $150 \mathrm{Ml}$, ten $\mathrm{mL} 65 \% \mathrm{HNO}_{3}$ (Suprapure, Merck, Darmstadt, Germany) was added to the Erlenmeyer flasks, and was slowly digested overnight after five $\mathrm{mL} \mathrm{HClO} \otimes, 70 \%$ was added to each sample (Suprapure, Merck, Darmstadt, Germany) (Mansouri et al. 2012). For digestion we used a hot plate (sand bath) at the first step at $200^{\circ} \mathrm{C}$, for about $6 \mathrm{~h}$ or until the solutions were clear after cooling, in the second step each sample was transferred to polyethylene bottles and deionized water was added until the sample equaled $25 \mathrm{~mL}$. In each set of eight samples, one control sample was prepared and examined. Then the solution was filtered using a $0.45 \mu \mathrm{m}$ nitrocellulose membrane filter. A Shimadzu AA 680 flame atomic absorption spectrophotometer was used for determining the concentrations heavy metals. The detection limits for $\mathrm{Cd}, \mathrm{Pb}, \mathrm{Ni}$ and $\mathrm{Zn}$ were $0.09,0.04,0.06 \mathrm{and} 0.09 \mu \mathrm{g} / \mathrm{g}$ respectively. Also, the obtained recoveries for $\mathrm{Cd}$, $\mathrm{Pb}, \mathrm{Ni}$ and $\mathrm{Zn}$ gave average of $88 \%$ and $105 \%$ respectively.

\subsection{Quality Control}

Procedural blanks and certified reference material (CRMs, e.g. DOLT-2 and DORM-2) were included in each sample batch. To determine the detection limit of heavy metals in the samples, blank samples were injected three times for analysis and the result with 3-times the standard deviation of the procedural blanks $(0.08,0.05,0.07 \mu \mathrm{g} / \mathrm{g}$ dw and $0.1 \mathrm{in} \mathrm{Cd}, \mathrm{Ni}, \mathrm{Pb}$ and $\mathrm{Zn}$ respectively). The precision and accuracy of the applied analytical method was determined based on CRMs, e.g. DOLT-2 and DORM-2 heavy metal in sample. The results of our CRMs measurements were a good estimate of the real values. In each sample batch, procedural blanks and certified reference material DOLT-2 and DORM-2 were included. For each matrix, analyses of three blank samples and analysis of reagent blanks was performed. In order to estimate the accuracy and precision of the chemical analysis; sample blanks, standard blanks and three analytical duplicates with the concentration of $1.2 \mu \mathrm{g} / \mathrm{g}$ were injected and their mean and its $95 \%$ confidence interval was calculated. Quantification was based on multi-level calibration on the concentrations of $0.1,0.5,3,15,50$ and $100 \mu \mathrm{g} / \mathrm{g}$; and then the standard calibration curve was drawn with $99 \%$ accuracy. All concentrations are expressed in $\mu \mathrm{g} \mathrm{g}^{-1}$ of $\mathrm{d} . \mathrm{w}$.

\subsection{Statistical analysis}

For data analysis we used SPSS (Version 20.0). The data were tested for normality using a Kolmogorov-Smirnov test. For determine normal distribution and homogeneity of variance of heavy metals levels in the tissue samples we use Kolmogorov-Smirnov test and after normal data, we were employed the parametric statistics. To test differences in total heavy metals level of samples among groups were performed a one-way ANOVA, and then the Duncan's post hoc test for differences in level between areas was used. Spearman's rank correlation coefficients were used to test for correlation among various heavy metals from birds. A p-value $<0.05$ was considered to indicate statistical significance.

\section{Results And Discussion}

\subsection{Total heavy metal concentrations in wild birds from Iran}

Zinc: The levels of heavy metals in brain liver, kidney and pectoral muscle samples of all samples in birds for this region are shown in Tables 1 . The highest median toxic concentrations were of $\mathrm{Ni}$, followed by $\mathrm{Pb}$ and $\mathrm{Cd}$; in particular, kidney and liver had the highest levels of $\mathrm{Ni}$, in brain the $\mathrm{Pb}$ have highest concentration $(2.7 \mu \mathrm{g} / \mathrm{g} \mathrm{dw})$. For the essential metal $(\mathrm{Zn})$ in all tissues analyzed, levels were the highest in brain ( $34.50 \mu \mathrm{g} / \mathrm{g} \mathrm{dw})$, followed by those of kidney $(21.30 \mu \mathrm{g} / \mathrm{g} \mathrm{dw})$, liver $(7.30 \mu \mathrm{g} / \mathrm{g} \mathrm{dw})$ and muscle $(7 \mu \mathrm{g} / \mathrm{g} \mathrm{dw})$. Studies have shown that there is homeostatic regulation of the intracellular essential metals in birds (Di Giulio and Scanlon 1984; Cosson et al. 1988; Kim et al. 1998; Barjaktarovic et al. 2002; Gomez et al. 2004; Zaccaroni et al. 2011).

Reports of toxicity Zn for wild birds in liver are (>122 ng/g dw(Gomez et al. 2004), ( > 440 n/g dw, (Beyer et al. 2004) and (700-1830 ng/g dw),(Sileo et al. 2003). Zn level in this study, of all wild birds were lower than the $Z n$ threat level for wild birds. The normal level of $Z n$ in the liver of mammals and birds usually does not exceed $525.0 \mu \mathrm{g} / \mathrm{g} \mathrm{dw}$ (Taggart et al. 2009) and our results show that none of the birds are above the level.

Compared to studies from Iran, Zn level in livers of this study were much lower than those of birds in Kanibarazan wetland (Alipour et al. 2016), Gomishan and Anzali wetlands (Aazami and KianiMehr 2018), but similar to birds in Miyankale and Gomishan wetlands (Sinka-Karimi et al. 2015). Compared to levels elsewhere in the world, Zn level in livers of this study were lower than those of waterfowl in Chesapeake Bay, USA (103-107 $\mu \mathrm{g} / \mathrm{g}$ dw) (Di Giulio and Scanlon 1984), Donana national park, Spain (52.5-138.9 $\mu \mathrm{g} / \mathrm{g} \mathrm{dw}$ ) (Taggart et al. 2006), Eastern Poland (30.2-279.38 $\mu \mathrm{g} / \mathrm{g} \mathrm{dw}$ ) (Komosa et al. 2012), Atlantic Canadian (84.7-173 $\mu \mathrm{g} / \mathrm{g} \mathrm{dw}$ ) (Elliott et al. 1992), Chaun, north east Siberia, Russia (82-201 $\mu \mathrm{g} / \mathrm{g} \mathrm{dw}$ ) (Kim et al. 1996), four Spanish wetland (94-144 $\mu \mathrm{g} / \mathrm{g}$ dw), lake

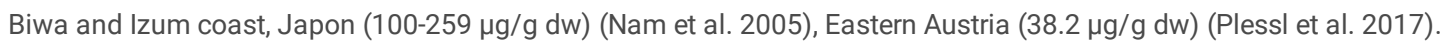


Lead: The threshold level for toxic exposure to $\mathrm{Pb}$ in liver and kidney of birds is $>6 \mu \mathrm{g} / \mathrm{g} \mathrm{dw}$ weight (Clark and Scheuhammer 2003); in this study one blackwinged stilt (Himantopus himantou) was higher than the threat level exposure to lead in livers of birds (13.9 $\mathrm{ng} / \mathrm{g}$ dry weight). Birds such as shovelers (Anas clypeata), greylag geese (Anser anser), snow geese, brant geese (Branta bernicla), mallards and black ducks from Northern California, USA (Hui et al. 1998), Canada (gosling) (Henny et al. 2000), four wetland in Spain (Mateo and Guitart 2003), and northern Idaho, USA (Blus et al. 1995) had levels of Pb in livers higher of the threshold level of threat exposure to $\mathrm{Pb}$ in livers. But birds in the Kanibarazan wetland (Alipour et al. 2016), Miyankaleh and Gomishan wetlands (Sinka-Karimi et al. 2015) from Iran, Eastern Poland (Komosa et al. 2012), Donana national park, Spain (Gomez et al. 2004), Illinois river (Levengood 2003), Eastern Austria (Plessl et al. 2017), were $>5 \mu \mathrm{g} / \mathrm{g}$ d.w, indicating the possibility of lead toxicity.

In birds, $\mathrm{Pb}$ concentrations in the brain $>5 \mathrm{ng} / \mathrm{g}$ d.w. are indicative of poisoning (Kalisinska 2000), and concentrations $>16 \mathrm{ng} / \mathrm{g} \mathrm{dw}$ indicate an advanced state of exposure, birds (Havera et al. 1992). In this study, none of the levels of $\mathrm{Pb}$ in the brains were higher than the toxic limit threshold.

In birds from Iran in this study, mean Pb concentrations were 0.57-4.7 $\mu \mathrm{g} / \mathrm{g}$ d.w. in liver and 0.60-8.73 $\mu \mathrm{g} / \mathrm{g}$ d.w. in kidney. The concentration Pb in liver were lower than those observed from Kanibarazan wetland, Iran (Alipour et al. 2016), Gomishan and Miyankaleh, Iran (Sinka-Karimi et al. 2015), Ebro Delta (Mateo and Guitart 2003) , lake Biwa and Mie Izum coast, Japan (Nam et al. 2005), El Hondo, Spain (Taggart et al. 2009), four Spanish wetland (Mateo and Guitart 2003), and were $\mathrm{m}$ higher than those observed from Atlantic Canadian, Canada (Elliott et al. 1992), wetland in north western Poland (Kalisińska et al. 2004), Eastern Poland (Komosa et al. 2012), Illinois river, USA (Levengood 2003), Eastern Austria (Plessl et al. 2017), Donana National Park, Spanish (Taggart et al. 2006). The concentration Pb in kidney were higher from Kanibarazan wetland, Iran (Alipour et al. 2016), Gomishan and Miyankaleh wetlands, Iran (SinkaKarimi et al. 2015), Donana Park, Spanish (Gomez et al. 2004), and Lake Biwa and Mie Izum coast, Japan (Nam et al. 2005), wetland in northwestern Poland (Kalisińska et al. 2004) and lower of Chesa Peak Bay, USA (Di Giulio and Scanlon 1984).

Cadmium: Concentrations of $\mathrm{Cd}>3 \mu \mathrm{g} / \mathrm{g}$ d.w. and $>8 \mu \mathrm{g} / \mathrm{g}$ d.w in liver and kidney suggest hazardous environmental exposure (Scheuhammer 1987), and levels greater than $40 \mu \mathrm{g} / \mathrm{g}$ d.w. and $100 \mu \mathrm{g} / \mathrm{g}$ d.w in the liver and kidney indicate toxicities (Degernes 2008). In this study, except for one black-winged stilt, Cd concentrations of livers were far below the estimated toxic threshold. Also, Cd concentration in one moorhen and one marsh sandpiper cadmium (Cd) of kidney were far below the estimated threshold (Scheuhammer 1987).

In birds from Iran in this study, mean cadmium concentrations $0.43-3.94 \mu \mathrm{g} / \mathrm{g}$ d.w. in liver and 0.47-7.47 $\mu \mathrm{g} / \mathrm{g} \mathrm{d}$.w. in kidney. The concentration Cd in liver were similar to those found in birds from Ebro Delta, Spain (Mateo and Guitart 2003), lake Biwa and Mie Izum coast, Japon (Nam and Lee 2006), Chesapeake Bay, USA (Di Giulio and Scanlon 1984), but were much lower than those observed from Pacific northwest Canada (Barjaktarovic et al. 2002), Chaun, northeast Siberia, Russia (Kim et al. 1996), and were much higher than those observed from Zator and Milicz, Poland (Binkowski and Sawicka-Kapusta 2015), Mississippi fly way (Custer et al. 2003), Eastern Poland (Komosa et al. 2012), Illinois river (Levengood 2003).

The concentration Cd in kidney were similar to those found in birds from Donana National Park, Spain (Gomez et al. 2004), Illinois river, USA (Levengood 2003) and lower of Zator and Milicz, Poland (Binkowski and Sawicka-Kapusta 2015), Chaun north east Siberia, Russia (Kim et al. 1996), Pacific northwest Canada (Barjaktarovic et al. 2002) and higher of lake Biwa and Mie Izum coast, Japon (Nam and Lee 2006), a wetland in north western Poland (Kalisińska et al. 2004), Kanibarazan wetland, Iran (Alipour et al. 2016) and Gomishan and Miyankaleh, Iran (Sinka-Karimi et al. 2015).

Nickle: According to studies, Ni concentrations > $10 \mu \mathrm{g} / \mathrm{g}$ d.w. in kidney, and > $3 \mu \mathrm{g} / \mathrm{g} \mathrm{d} . \mathrm{w}$. in the liver are toxic in wild birds (Outridge and Scheuhammer 1993). In this study, $56 \% \mathrm{Ni}$ concentrations in liver, and $56 \%$ kidney concentrations in birds were higher than the toxicity level.

In birds, Ni concentrations in liver and kidney are seldom studied. Concentrations of Ni in livers of birds in this study were higher than those from Connecticut, USA (Barclay et al. 1995) Gdansk Bay, Poland (Szefer and Falandysz 1986), San Francisco Bay, USA (Ohlendorf et al. 1986), Jamaica Bay, USA (Burger and Gochfeld 1985), Wrangel Island, Russia (Hui 1998), Florida lake from South Africa (Vaneeden and Schoonbee 1992). Concentrations of Ni in the kidney of birds in this study were higher than those from Southwest Atlantic coast, France (Lucia et al. 2010), Gdansk Bay Baltic sea, Poland (Szefer and Falandysz 1987a) and wetland in north western Poland (Kalisińska et al. 2004).

\subsection{Variation among Organs}

In this study, the levels of heavy metals in muscle tissue were lower than in other tissues, and our results agree with other studies that reported that muscle tissue was not an active tissue for accumulating these heavy metals. Also, in this study the brains of birds had the highest concentration of metals except $\mathrm{Ni}(\mathrm{P}<0.05)$. Analysis of heavy metals in the internal organs of birds allows for assessment of environmental pollution. The level of metal a body absorbs and accumulates depends on the level of exposure, the chemical form of an element, the interaction toxins with elements, and physiological factors of the bird species (Gochfeld and Burger 1987). Accumulation of pollutants in the internal organs of their bodies is greatly affected by the contaminant level of the food and water ingested. Liver and kidney are sites of detoxification and reflect long-term bioaccumulation, and attributed to the longer period during which they have survived to accumulate more metals (Burger and Gochfeld 2016), while muscle and brain only are sites of accumulation, and not of detoxification (Janaydeh et al. 2016).

If birds are exposed to high concentrations of $\mathrm{Pb}$ and $\mathrm{Cd}$, these elements will be accumulating in high concentrations in the brains of these birds, such as in white-tailed eagle and scavenging gulls, increasing the metals. Brain tissue levels were related to dietary contamination (Hulse et al. 1980; Szefer and Falandysz 1987b). Relatively low (up to $0.4 \mathrm{ppm}$ wet wt) lead (Pb), but not cadmium (Cd), levels were recorded in the brain of pelagic seabirds (Morris et al. 1992; Rice 1992). Redknobbed coots (Fulica cristata) from industrialized and polluted region of South Africa had Pb levels in brain that increased to 25 ppm d.w., 2 and 4 times as much as in kidneys and liver (Vaneeden and Schoonbee 1992). These studies on the accumulation of heavy metals in the brain of birds should be further compared to other organs of the body. Different adaptations of birds to the environment, as well as the reaction and function of the brain against different contaminants, can be one of the factors affecting the absorption of contaminants in birds' brains. There are few studies of the levels of 
heavy metals in the brain tissue of birds. Compared to other studies, the level of heavy metals in brain tissues in this study were higher than other studies in other parts of the world, including Zator and Milicz, Poland (Binkowski and Sawicka-Kapusta 2015), wetland in north western Poland (Kalisińska et al. 2004), Gdansk Bay Baltic Sea, Poland (Szefer and Falandysz 1987b) Nilgiris, Tamil Nadu, India (Jayakumar and Muralidharan 2011), lagoon of Marano, Italy (Leonzio et al. 1986), Bjørøya and Jan Mayen Artic (Malinga et al. 2010), Pomeranian Bay, Poland (Kalisińska and Szuberla 1996).

The highest Ni levels were recorded in kidneys, liver and muscles showed slightly lower levels, and the lowest levels were found in the brain (Figure 2). A significant difference was observed in Ni levels between kidney and the liver, brain and muscles $(P>0.05)$

\subsection{Relationship between metal levels, feeding habits, and migration status}

The most important factors that affect the concentration of metals among different species are the diet and feeding habits (Dahmardeh Behrooz et al. 2009a). Diet varies between different bird species depending on the foraging strategies and diet preferences. One of the key ways for metals to enter the body of birds is through food, water, and by eating of sediment, lead shot and grit (non-food items). The direct consumption of soil contaminated with metals is a major cause of increased contamination in their bodies, even if the contaminant levels in plants or their prey has not increased (Beyer et al. 1998).

In this study birds were divided into four groups: invertebrate predator, fish predator, fish and crab predator, and omnivorous to examine the effects of type of food on metal levels, using published data (Mansoori 2008; Dahmardeh Behrooz et al. 2009a). In the fourth group, we had only the Eurasian spoonbill $(\mathrm{n}=1)$, so it was excluded from the statistical tests. Diet type had a significant effect on levels of $\mathrm{Zn}, \mathrm{Pb}, \mathrm{Cd}$ and Ni in the kidney and liver, with invertebrate species having greater concentrations than fish predators and omnivores $(P<0.05)$. There were no statistically significant differences for brain and muscle levels for any of the metals examined.

In a study in Shadegan wetland from Iran on mercury pollution in three species of waders, Black-winged stilt had higher levels of mercury in the feathers, liver, kidneys, and muscles than other birds in the study (Zamani-Ahmadmahmoodi et al. 2010). The reason for the increase in mercury in this bird compared to other birds was that its' long legs allowed access to deeper parts of the water and stilts could hunt larger prey than invertebrates. Similarly, other authors found higher heavy metal levels in the larger species that had access to larger sections of the water, and could hunt larger prey (Burger and Gochfeld 1992). In the present study, the reason for the increase in metals in the various organs of these black-winged stilt, marsh sandpiper and northern lapwing was their feeding on agricultural lands irrigated by farmers. We, and others (D Mansoori, 2008) suggest that these species feed more on agricultural lands than do other species, remaining on the water for several days, rather than on the shores of the Chahnimeh from Sistan. Perhaps the use of chemical fertilizers and pesticides in agricultural lands has increased the exposure of birds to metals. This difference in metal concentration is most likely due to metal biogeochemical behavior, diet, and accidental ingestion of fine soil and sediment particle. However, it is impossible to separate soil selection/soil digestion and diet. Certainly these two exposure pathways are very effective in concentrating these metals because other metals are correlated with accidental ingestion of fine soil and sediment particle (Alloway 2012). In our study of heavy metals, birds that are herbivores compared to birds that are prredators had higher concentrations of heavy metals in the liver (Okati 2013) (Parslow et al. 1982), (Brennan et al. 1992).

Birds of Chahnimeh reservoirs were divided into 2 groups of long-distance migrants and local migrants that only go to the northern rivers and wetlands of Iran and do not leave Iran. It is noteworthy that there were differences in levels between the internal organs of the kidney and liver for all four elements studied, but no statically significant difference was observed between the two groups of birds for brain and muscle tissue (Table 3). The birds in south wetlands from Iran migrate to north wetlands in provinces Gilan and Mazandarn in south Caspian sea to avoid the hot summer months in south and south east Iran, (Mansoori 2008; Dahmardeh Behrooz et al. 2009b). Heavy metal levels are high in this region of Iran in water, Caspian Sea, fishes, macroalga, sediment and water (Adel et al. 2016; Ebadi and Hisoriev 2017a, b; Malvandi 2017). This higher level of heavy metals in biotic and abiotic environment in south Caspian Sea might explain the high level of these heavy metals in birds in local migrants.

Lower median concentrations of heavy metals $(\mathrm{Cd}, \mathrm{Pb}, \mathrm{Ni}$ and $\mathrm{Zn})$ in liver and kidney were detected in the long-distance migrant birds than the local migrants $(P>0.05)$ (Figure 1). Low usage of heavy metals and pesticides in breeding regions birds (Siberia or Eastern Europe) (Dahmardeh Behrooz et al. 2009b) that have migrated out of Iran might explain lower heavy metals in these birds.

\subsection{Correlations among heavy metals}

All four elements in this study were positively correlated with each other within organs $(P>0.001, r>0.777)$, but none of the elements were positively correlated with the other element in other tissue. This shows that the pathways and sources of entry for the elements studied are similar, but the pathways for the accumulation of these elements and the reactions of different organs of the body to these elements, are very different.

A positive correlation between levels of $\mathrm{Zn}$ and $\mathrm{Cd}$ in the body of birds may protect them from the effects of increasing Cd in the body (Cosson et al. 1988; Elliott et al. 1992). Positive correlations of $\mathrm{Pb}$ or $\mathrm{Cd}$ with other element level in tissues have been reported in birds from Korea (Kim and Oh 2012), shorebirds from Korea (Kim et al. 2009), Cory's shearwater (Calonectris diomedea) and black-backed gulls (Larus fuscus) from England (Stewart et al. 1995), seabirds from Chaun, northeast Siberia, Russia (Kim et al. 1996), and feral pigeons (Columba livia) from Korea (Nam and Lee 2006).

\section{Health Risk Thresholds}

One of non-essential element in the body is lead $(\mathrm{Pb})$ that can cause neurotoxicity, nephrotoxicity and other health effects (Garcia-Leston et al. 2010). Both Spanish legislation and Australian National Health and Medical Research Council (ANHMRC) proposed $2.0 \mu \mathrm{g} / \mathrm{g}$ ww as the maximum permitted level of Pb in food (Plaskett and Potter 1979; El-Sikaily et al. 2004). The median level of Pb in muscle tissue all 9 species birds, except for Eurasian spoonbill, great crested grebe and moorhen, was lower than the Spanish legislation and ANHMRC. The median level of lead in the liver of birds was higher than the Spanish legislation and ANHMRC except for cormorant and in kidney of all birds except cormorant and eurasian spoonbill were higher of this guideline (Figure 3 ). 
Also, $11.7 \mu \mathrm{gg}$ w.w Pb is the action level for human health (USFDA 1993), and according to this guideline median level Pb in muscle of all birds (except cormorant), and liver and kidney in all birds, were higher than this guideline (Figure 3 ). In contrast to these maximum permitted levels for Pb, the Institute of Turkish Standards for Food (ITSF) and European Commission (EC) introduced the permissible level threshold of 0.1 and $0.5 \mu \mathrm{g} / \mathrm{g}$ ww respectively (EC 2001 ; Dirican et al. 2013). The median level in flesh muscle, liver, and kidney of all birds in this study were clearly higher than these guidelines, and according to these two guidelines, the health of the people of this region is endangered by consuming the muscle, and especially the liver of these birds.

The maximum permitted Cd level of ANHMRC, USFDA and Western Australian authorities are $2,3.7$ and $5.5 \mu \mathrm{g} / \mathrm{g}$ ww respectively; in this study none of the birds exceeded this median level $\mathrm{Cd}$ in muscle, but levels of $\mathrm{Cd}$ in liver of northern lapwing, moorhen, marsh sandpiper and black-winged stilt were higher than the threshold levels suggested by ANHMRC, USFDA and Western Australian authorities (Plaskett and Potter 1979; El-Sikaily et al. 2004). Cadmium levels in kidney were higher than the ANHMRC in all birds except the cormorant and the Eurasian spoonbill. Also, the great crested grebe, with level $4 \mu \mathrm{g} / \mathrm{g}$ ww, was higher than both ANHMRC and USFDA, and the rest of the birds were higher than all three guideline ANHMRC, USFDA and Western Australian authorities (Figure 3). In contrast to these maximum permitted levels, the Spanish legislation and EC threshold is 1 and $0.05 \mu \mathrm{g} / \mathrm{g}$ w.w. respectively (Plaskett and Potter 1979; El-Sikaily et al. 2004). In this study, levels of Cd in muscle, liver and kidney of all birds were greater than these thresholds.

The permissible limit of Ni food by the US Food and Drug Administration is $10 \mu \mathrm{g} / \mathrm{g}$ ww (USFDA, 1993). According to this guideline, the levels of Ni in muscle, liver and kidney of all birds, except cormorant, were higher than the permissible limit. The permissible limit of FAO Ni is $13 \mu \mathrm{g} / \mathrm{g}$ ww in food (FAO 1983), and level $\mathrm{Ni}$ in muscle birds lower of this limit were but in liver birds black-winged stilt, marsh sandpiper, moorhen and northern lapwing were higher of $13 \mu \mathrm{g} / \mathrm{g}$ ww and in kidney all birds except cormorant and Eurasian spoonbill were higher of guideline FAO (Figure 3). The Food and Nutrition Board (FNB) (FNB, 2010) introduced the permissible limit of $\mathrm{Ni}$ as $4 \mu \mathrm{g} / \mathrm{g}$ w.w; accordingly, all muscle, liver and kidney in all birds in the present study were higher than this limit, and consumption of edible parts of all birds are a threat for heath people in this region.

The ANHMRC and WHO introduced an acceptable limit $1000 \mu \mathrm{g} / \mathrm{g}$ w.w for $\mathrm{Zn}$ in food. The level of $\mathrm{Zn}$ in muscle, liver and kidney in all birds of Zabol Chahnimeh reservoirs were below this toxic threshold (Plaskett and Potter 1979) (Cliton et al. 2008). (Figure 3).

\subsection{Health threat from Consuming birds in Chanimeh reservoir}

To assess the health effects and compare them with standards, we converted g/dry weight to g/wet weight (the ratio of dry weight to fresh weight is 0.3 ). In this study, the THQ was assessment accordingly to the guidelines of the United States Environmental Protection Agency and the level of absorption of heavy metals is equal to the absorption of ingestion (assuming that cooking does not effect the level of metals) (USEPA 1989). Furthermore, because of the unavailable oral reference dose (RfDo) of $\mathrm{Pb}$, the value is specified as the permissible tolerable daily intake (PTDI) suggested by the Joint FAO/WHO Expert Committee on Food Additives (JECFA) 2013).

In this study, we calculated the THQ from the following equation:

$$
T H Q=\frac{E F \times E D \times M S \times C}{R f D o \times B W \times A T} \times 0.001
$$

When THQ (Target Hazard Quotient) is > 1 systemic effect may occur and in fact the THQ is the ratio between exposure and reference dose (Copat 2014). $\operatorname{RfDo}(\mu \mathrm{g} / \mathrm{g} /$ day) is an estimate with uncertainty and magnification of the daily exposure of human populations including sensitive subgroups without an appreciable risk of deleterious effects during a lifetime. The RfDo values used in this study were $0.001,0.02,0.004$ and $0.3 \mathrm{for} \mathrm{Cd}, \mathrm{Ni}, \mathrm{Pb}$ and $\mathrm{Zn}$ respectively. The exposure frequency is EF that in this study is about 182.5, exposure duration is ED ( 72 years), meal size is MS (about 95) (Sinkakarimi et al. 2013), and $20 \mathrm{~g}$ for kidney and liver (Mahmoud et al. 2015). C is the metal concentration ( $\mu \mathrm{g} / \mathrm{g} \mathrm{w} . w \mathrm{w}$ ).(US EPA 2009; JECFA 2013). The body weight is BW ( $70 \mathrm{~kg}$ ) (US EPA 1989) and $\mathrm{EF} \times \mathrm{ED}=\mathrm{AT}$ that is average time.

$\mathrm{THQ}=\sum \mathrm{THQ} \mathrm{toxicant} 1+\mathrm{THQ} \mathrm{toxicant} 2+\ldots \ldots+\mathrm{THQ}$ toxicant $\mathrm{n}$ (Chien et al. 2002)

The level $\mathrm{HQ}$ in any of the metals in the muscle of birds was not more than one, but the $\sum \mathrm{HQ}$ was higher than one in $\mathrm{M}$. (Table 4). The level $\mathrm{HQ}$ of $\mathrm{Pb}$ in liver $\mathrm{B}$ was higher of one and in the other birds wasn't element higher than 1 and even $\sum \mathrm{HQ}$ was not higher than 1 (Table 4). In kidney level HQ of Pb in N, M, MS and $\mathrm{B}$ was higher of 1 and also, these birds the $\sum \mathrm{HQ}$ in the others birds was between $>1$. In the edible parts, the level of $\mathrm{HQ}$ was high and except $\mathrm{C}$ in the others birds between level $\sum \mathrm{HQ}$ was 1.24 to 4 , and this due to the high level of $\mathrm{HQ}$ in the kidneys and muscle of birds in this region (Figure 4). The $\sum \mathrm{HQ}$ of each metal we examined was higher $>1$, suggesting that people would not experience health risks from consumption of birds from the Chahnimeh reservoirs (Figure 4). On the other hand, values of the $\sum H Q$ index for total exposure were higher $>1$ for birds, indicating that the estimated exposure is a major health concern. Researchers' studies in the wetlands of northern Iran showed that the Pochard bird is not suitable for consumption like our birds (Sinkakarimi et al. $2015 \mathrm{a}$ ).

\subsection{Estimated Human daily and weekly toxic elements intake from birds}

We calculated estimated daily intake (EDI) and estimated weekly intake (EWI) based on daily and weekly consume of birds (including liver and kidney muscle).

The estimated daily intake and estimated weekly intake calculated as follows: 


$$
\begin{aligned}
& E D I(\mu \mathrm{g} / \mathrm{g} / \text { daily })=\frac{M S \times C}{B W} \\
& E D I(\mu \mathrm{g} / \mathrm{g} / \text { week })=\frac{M S \times C}{B W}
\end{aligned}
$$

Different metals in different concentrations have different effects on organisms, and some metals can show toxic effects even in low concentrations (Mahmoud et al. 2015). In this study we examine EWI and EDI and then compared it with Provisional permissible tolerable weekly intake ( $\mu \mathrm{g} / \mathrm{kg}$ body weight/week) (PTWI), PTWI 70 that is PTWI for $70 \mathrm{~kg}$ person ( $\mu \mathrm{g} /$ week) and PTDI (Permissible tolerable daily intake) for a $70 \mathrm{~kg}$ person ( $\mu \mathrm{g} / \mathrm{day})$. The PTWI, PTWI 70 and PTDI depends on the level pollution, dietary period of dietary foodstuffs. The Food and Agriculture Organization and World Health Organization in 2004 established Provisional permissible tolerable weekly intake for Pb and Cd of 7 and $25 \mu \mathrm{g} / \mathrm{kg}$ body weight/ week for people, equaling 490 , $1750 \mu \mathrm{g} /$ week for $70 \mathrm{~kg}$ that is mean body weight in Iran person, respectively (JECFA 2004). Also, the PTWI according to guidelines of FAO/WHO ( 2011 ) are 35 and $7000 \mu \mathrm{g} / \mathrm{kg}$ body weight/ week for nickel and zinc, equaling 2450 and $490000 \mu \mathrm{g} /$ week for a $70 \mathrm{~kg}$ person, respectively (JECFA 2011).

According to Table 4, none of the bird organs had levels of $\mathrm{Zn}, \mathrm{Pb}, \mathrm{Cd}$ and $\mathrm{Ni}$ that were higher than the level of PTWI70. In this study, the EWI of Pb in edible parts of birds B, MS, M, N and E was higher than PTWI, and this is due to the high level of EWI in the liver of these birds, while the level of lead in the muscle tissue of all birds was within the allowable range PTDI, PTWI and PTWI 70.

For Cd, the level EWI in the edible parts was higher than PTWI in all birds, and the EDI level in edible parts birds G, B, MS, M and N was higher of PTWT, which is due to the high level of EWI and EDI in the muscle and kidneys of these birds (Table 4).

In this study of Ni, the level EWI in muscle and edible parts was higher than PTWI in all birds, and level EWI was higher in B, MS, M and N of PTDI. Also EDI in the birds B, N, M and MS was higher than the level of PTWI. Except C and E, in all birds that EWI in kidney them was higher of PTWI, also level Ni in liver birds $\mathrm{B}, \mathrm{Ms}, \mathrm{N}$ and $\mathrm{M}$ level EWI was higher of PTWI (Table 4). Level EDI of Ni in edible parts B, Ms, N and M was higher of PTWI and also level Ni in kidney $\mathrm{M}$ and Ms higher of PTWI, and finally, the data indicate that level EWI in edible parts B, MS, M and N was higher of PTDI (Table 4). The results of this study show that people in this area should not use edible parts, and the use of wild birds as daily and weekly food is a serious threat to the inhabitants of this area. This is contrary to the results obtained for birds in the wetlands of northern Iran, where EDI and EWI were within the permissible range and did not pose a threat to the people of the region (Sinkakarimi et al. 2015a, b).

\section{Conclusion}

In this study, levels of $\mathrm{Cd}, \mathrm{Pb}, \mathrm{Ni}$ and $\mathrm{Zn}$ were investigated in birds of Chahnimeh of Sistan from Iran. The level of all heavy metals (except nickel) in the brains of birds was higher than levels in other tissues. Differences in metals levels as a function of feeding habitat and migration were observed only in the kidney and liver tissues of birds. The levels of heavy metals in some birds were higher than an effects level threshold; $56 \%$ of the liver and kidneys samples of these birds were above the threat level. The results of this study show that birds in Chahnimeh of Sistan are at risk of heavy metal contamination. The data show that human consumption (using EDI, EWI and $\mathrm{HQ}$ ) of the edible tissues of birds is not suitable: people of the region should avoid eating the edible tissues of wild birds, and should avoid eating kidney and liver tissue.

\section{Declarations}

Author contributions: Conceptualization, Formal analysis, data curation, investigation, Reza Dahmardeh Behrooz; methodology, review \& editing Joanna Burger. All authors have read and agreed to the published version of the manuscript.

Declaration of interests The authors declare that they have no known competing financial interests or personal relationships that could have appeared to influence the work reported in this paper.

Availability of data and materials The authors declared that the data and materials for this work are available.

Conflict of interest The authors declared that there is no conflict of interest among them. All the authors read and approved the manuscript.

Ethics approval and consent to participate All procedures performed in studies involving collection birds and people who participated in this study were in accordance with the ethical standards of the institutional and/or national research committee University of Zabol with reference number IR.UOZ.REC.1399.005.

Consent for publication I understand that the text and any pictures published in the article will be freely available on the internet and may be seen by the general public. The pictures, and text may also appear on other websites or in print, may be translated into other languages or used for commercial purposes.

Funding Information: This work was funded by the University of Zabol, Project code PR-UOZ 99-4.

\section{References}

Aazami J, KianiMehr N (2018) Survey of heavy metals in internal tissues of Great cormorant collected from southern wetlands of Caspian Sea, Iran. Environ Monit Assess 190:52. https://doi.org/10.1007/s10661-017-6433-1

Page $7 / 15$ 
Abbasi NA, Jaspers VLB, Chaudhry MJI, et al (2015) Influence of taxa, trophic level, and location on bioaccumulation of toxic metals in bird's feathers: a preliminary biomonitoring study using multiple bird species from Pakistan. Chemosphere 120:527-537

Adel M, Dadar M, Fakhri Y, et al (2016) Heavy metal concentration in muscle of pike (Esox lucius Linnaeus, 1758) from Anzali international wetland, southwest of the Caspian Sea and their consumption risk assessment. Toxin Rev 35:217-223

Alipour H, Solgi E, Majnouni F (2016) Concentrations of Heavy Metals in tissues of the Mallard Anas platyrhynchos in Kanibarazan, northwestern Iran. Podoces 11:35-42

Alloway BJ (2012) Heavy metals in soils: trace metals and metalloids in soils and their bioavailability. Springer Science \& Business Media

Aloupi M, Karagianni A, Kazantzidis S, Akriotis T (2017) Heavy Metals in Liver and Brain of Waterfowl from the Evros Delta, Greece. Arch Environ Contam Toxicol 72:215-234. https://doi.org/10.1007/s00244-016-0349-6

Ariyaee M, Azadi NA, Majnoni F, Mansouri B (2015) Comparison of Metal Concentrations in the Organs of Two Fish Species from the Zabol Chahnimeh Reservoirs, Iran. Bull Environ Contam Toxicol 94:715-721. https://doi.org/10.1007/s00128-015-1529-1

Barclay JS, Perkins CR, Tomassone ME, Eccleston KE (1995) Declining populations of ducks as influenced by habitat quality in the Long Island Sound. Proj numbers CWF226-R CWF

Barjaktarovic L, Elliott JE, Scheuhammer AM (2002) Metal and Metallothionein Concentrations in Scoter ( Melanitta spp.) from the Pacific Northwest of Canada, 1989-1994. Arch Environ Contam Toxicol 43:486-491. https://doi.org/10.1007/s00244-002-1273-5

Bazrafshan E, Mostafapour FK, Esmaelnejad M, et al (2016) Concentration of heavy metals in surface water and sediments of Chah Nimeh water reservoir in Sistan and Baluchestan province, Iran. Desalin Water Treat 57:9332-9342. https://doi.org/10.1080/19443994.2015.1027958

Beyer WN, Dalgarn J, Dudding S, et al (2004) Zinc and Lead Poisoning in Wild Birds in the Tri-State Mining District (Oklahoma, Kansas, and Missouri). Arch Environ Contam Toxicol 48:108-117. https://doi.org/10.1007/s00244-004-0010-7

Beyer WN, Day D, Morton A, Pachepsky Y (1998) Relation of lead exposure to sediment ingestion in mute swans on the Chesapeake Bay, USA. Environ Toxicol Chem An Int J 17:2298-2301

Binkowski ŁJ, Sawicka-Kapusta K (2015) Cadmium concentrations and their implications in Mallard and Coot from fish pond areas. Chemosphere 119:620625. https://doi.org/10.1016/j.chemosphere.2014.07.059

Blus LJ, Henny CJ, Hoffman DJ, Grove RA (1995) Accumulation in and effects of lead and cadmium on waterfowl and passerines in northern Idaho. Environ Pollut 89:311-318

Brennan KG, Noller BN, Le Gras C, et al (1992) Heavy metals in waterbirds from the Magela Creek flood plain, Alligator Rivers Region, Northern Territory

Burger J, Diaz-Barriga F, Marafante E, et al (2003) Methodologies to examine the importance of host factors in bioavailability of metals. Ecotoxicol Environ Saf $56: 20-31$

Burger J, Gochfeld M (2016) Habitat, population dynamics, and metal levels in colonial waterbirds: a food chain approach. CRC Press

Burger J, Gochfeld M (1985) Comparisons of nine heavy metals in salt gland and liver of greater scaup (Aythya marila), black duck (Anas rubripes) and mallard (A. platyrhynchos). Comp Biochem Physiol C 81:287-292

Burger J, Gochfeld M (1992) E nvironmental Trace Element Distribution in Growing Feathers: Additional Excretion in Feather Sheaths. 108:105-108

Chien L-C, Hung T-C, Choang K-Y, et al (2002) Daily intake of TBT, Cu, Zn, Cd and As for fishermen in Taiwan. Sci Total Environ 285:177-185

Clark AJ, Scheuhammer AM (2003) Lead poisoning in upland-foraging birds of prey in Canada. Ecotoxicology 12:23-30

Cliton HI, Ujagwung GU, Michael H (2008) Trace metals in the tissues and shells of Tympanotonus Fuscatus var. Radula from the Mangrove Swamps of the Bukuma Oil Field, Niger Delta. Eur J Sci Res 24:468-476

Cosson RP, Amiard J-C, Amiard-Triquet C (1988) Trace elements in little egrets and flamingos of Camargue, France. Ecotoxicol Environ Saf 15:107-116

Custer CM, Custer TW, Anteau MJ, et al (2003) Trace elements in lesser scaup (Aythya affinis) from the Mississippi flyway. Ecotoxicology 12:47-54

Dahmardeh Behrooz R, Esmaili-Sari A, Ghasempouri SM, et al (2009a) Organochlorine pesticide and polychlorinated biphenyl residues in feathers of birds from different trophic levels of South-West Iran. Environ Int 35:285-290. https://doi.org/10.1016/j.envint.2008.07.001

Dahmardeh Behrooz R, Esmaili-Sari A, Ghasempouri SM, et al (2009b) Organochlorine Pesticide and Polychlorinated Biphenyl in Feathers of Resident and Migratory Birds of South-West Iran. Arch Environ Contam Toxicol 56:803-810. https://doi.org/10.1007/s00244-008-9211-9 
Dahmardeh Behrooz R, Sahebi S, Majnoni F, et al (2013) Mercury contamination in commercial fresh and salt water fish of the Zabol Chahnimeh reservoirs and the Gulf of Oman (Iran). Food Addit Contam Part B 6:175-180. https://doi.org/10.1080/19393210.2013.779322

de Luis DA, Gonzalez Sagrado M, Aller R, et al (2011) Metabolic syndrome and ALA54THR polymorphism of fatty acid-binding protein 2 in obese patients. Metabolism 60:664-668. https://doi.org/10.1016/j.metabol.2010.06.018

Degernes LA (2008) Waterfowl toxicology: a review. Vet Clin North Am Exot Anim Pract 11:283-300

Di Giulio RT, Scanlon PF (1984) Heavy metals in tissues of waterfowl from the Chesapeake Bay, USA. Environ Pollut Ser A, Ecol Biol 35:29-48. https://doi.org/10.1016/0143-1471(84)90128-4

Dirican S, Çilek S, Çiftçi H, et al (2013) Preliminary study on heavy metal concentrations of Anatolian Khramulya, Capoeta tinca (Heckel, 1843) from Çamlર\i\}göze Dam Lake, Sivas, Turkey. J Environ Heal Sci Eng 11:7

Ebadi AG, Hisoriev H (2017a) The prevalence of heavy metals in Cladophora glomerata L. from Farahabad Region of Caspian Sea-Iran. Toxicol Environ Chem 99:883-891

Ebadi AG, Hisoriev H (2017b) Metal pollution status of Tajan River-Northern Iran. Toxicol Environ Chem 99:1358-1367

EC (2001) Commission Regulation (EC) No. 466/2001 of 8 March 2001 setting maximum levels for certain contaminants in foodstuffs. 77:1-13

El-Sikaily A, Khaled A, El Nemr A (2004) Heavy metals monitoring using bivalves from Mediterranean Sea and Red Sea. Environ Monit Assess 98:41-58

Elliott JE, Scheuhammer AM, Leighton FA, Pearce PA (1992) Heavy metal and metallothionein concentrations in Atlantic Canadian seabirds. Arch Environ Contam Toxicol 22:63-73. https://doi.org/10.1007/BF00213303

Espin S, Garcia-Fernández AJ, Herzke D, et al (2016) Tracking pan-continental trends in environmental contamination using sentinel raptors-what types of samples should we use? Ecotoxicology 25:777-801

Frederick PC, Spalding MG, Sepälveda MS, et al (1999) Exposure of great egret (Ardea albus) nestlings to mercury through diet in the Everglades ecosystem. Environ Toxicol Chem An Int J 18:1940-1947

Garcia-Leston J, Méndez J, Pásaro E, Laffon B (2010) Genotoxic effects of lead: an updated review. Environ Int 36:623-636

Gomez G, Baos R, Gomara B, et al (2004) Influence of a Mine Tailing Accident Near Dooana National Park (Spain) on Heavy Metals and Arsenic Accumulation in 14 Species of Waterfowl (1998 to 2000). Arch Environ Contam Toxicol 47:521-529. https://doi.org/10.1007/s00244-004-0189-z

Havera SP, Wood SG, Georgi MM (1992) Blood and tissue parameters in wild mallards redosed with lead shot. Bull Environ Contam Toxicol 49:238-245

Henny CJ, Blus LJ, Hoffman DJ, et al (2000) Field evaluation of lead effects on Canada geese and mallards in the Coeur d'Alene River Basin, Idaho. Arch Environ Contam Toxicol 39:97-112

Honda K, Min BY, Tatsukawa R (1986) Distribution of heavy metals and their age-related changes in the eastern great white egret, Egretta alba modesta, in Korea. Arch Environ Contam Toxicol 15:185-197

Hui A, Takekawa JY, Baranyuk V V, Litvin K V (1998) Trace element concentrations in two subpopulations of lesser snow geese from Wrangel Island, Russia. Arch Environ Contam Toxicol 34:197-203

Hulse M, Mahoney JS, Schroder GD, et al (1980) Environmentally acquired lead, cadmium, and manganese in the cattle egret, Bubulcus ibis, and the laughing gull, Larus atricilla. Arch Environ Contam Toxicol 9:65-77

Janaydeh M, Ismail A, Zulkifli SZ, et al (2016) The use of feather as an indicator for heavy metal contamination in house crow (Corvus splendens) in the Klang area, Selangor, Malaysia. Environ Sci Pollut Res 23:22059-22071. https://doi.org/10.1007/s11356-016-7223-y

Jayakumar R, Muralidharan S (2011) Metal contamination in select species of birds in Nilgiris district, Tamil Nadu, India. Bull Environ Contam Toxicol 87:166170. https://doi.org/10.1007/s00128-011-0323-y

JECFA (2013) World Health Organization. Evaluations of the Joint FAO/WHO Expert Committee on Food Additives (JECFA) [Online]. [cited 2013]; Available from: URL: http://apps.who.int/food-additivescontaminants-jecfa-database/search.aspx?fc=47. World Health Organization

JECFA (2004) Joint FAO/WHO Expert Committee on Food Additives, Summary of Evaluations Performed by the Joint FAO/WHO Expert Committee on Food Additives (JECFA 1956- 2003), (First through sixty-first meetings). Food and Agriculture Organization of the United Nations an

JECFA (2011) Joint FAO/WHO Expert Committee on Food Additives. [http://www.who.int/foodsafety/ chem/jecfa/about/en/index.html. World Health Organization

Kalisinska E (2000) Lead and other heavy metals in the brain of geese hunted in the vicinity of Slonsk, Poland. Biol Bull Poznań 37 : 
Kalisińska E, Salicki W, Mysłek P, et al (2004) Using the Mallard to biomonitor heavy metal contamination of wetlands in north-western Poland. Sci Total Environ 320:145-161. https://doi.org/10.1016/j.scitotenv.2003.08.014

Kalisińska E, Salicki W, others (2010) Lead and cadmium levels in muscle, liver and kidney of scaup Aythya marila from Szczecin Lagoon, Poland. Pol J Env Stud 19:1213-1222

Kalisińska E, Szuberla U (1996) Heavy metals in the brain of long-tailed duck (Clangula hyemalis) wintering in the Pomeranian Bay, Poland. Biol Trace Elem Res 55:191-197. https://doi.org/10.1007/BF02784180

Kanwal S, Abbasi NA, Chaudhry MJI, et al (2020) Oxidative stress risk assessment through heavy metal and arsenic exposure in terrestrial and aquatic bird species of Pakistan. Environ Sci Pollut Res 27:12293-12307. https://doi.org/10.1007/s11356-020-07649-z

Kim EY, Goto R, Tanabe S, et al (1998) Distribution of 14 elements in tissues and organs of oceanic seabirds. Arch Environ Contam Toxicol 35:638-645

Kim EY, Ichihashi H, Saeki K, et al (1996) Metal accumulation in tissues of seabirds from Chaun, northeast Siberia, Russia. Environ Pollut 92:247-252. https://doi.org/10.1016/0269-7491(96)00007-3

Kim J, Lee H-S, Koo T-H (2009) Heavy metal concentrations in three shorebird species from Okgu Mudflat, Gunsan, Korea. Ecotoxicology 18:61-68

Kim J, Oh J-M (2012) Metal levels in livers of waterfowl from Korea. Ecotoxicol Environ Saf 78:162-169. https://doi.org/10.1016/j.ecoenv.2011.11.021

Komosa A, Kitowski I, Komosa Z (2012) Essential trace (Zn, Cu, Mn) and toxic (Cd, Pb, Cr) elements in the liver of birds from Eastern Poland. Acta Vet Brno 62:579-589. https://doi.org/10.2298/AVB1206579K

Leonzio C, Fossi C, Focardi S (1986) Heavy metals and selenium variation in a migratory bird wintering in a mercury-polluted lagoon. Bull Environ Contam Toxicol 37:219-225. https://doi.org/10.1007/BF01607753

Levengood JM (2003) Cadmium and lead in tissues of Mallards (Anas platyrhynchos) and Wood Ducks (Aix sponsa) using the Illinois River (USA). Environ Pollut 122:177-181. https://doi.org/10.1016/S0269-7491(02)00298-1

Lucia M, André J-MM, Gontier K, et al (2010) Trace element concentrations (mercury, cadmium, copper, zinc, lead, aluminium, nickel, arsenic, and selenium) in some aquatic birds of the Southwest Atlantic Coast of France. Arch Environ Contam Toxicol 58:844-853. https://doi.org/10.1007/s00244-009-9393-9

Mahmoud MAM, Abdel-Mohsein HS, others (2015) Health risk assessment of heavy metals for Egyptian population via consumption of poultry edibles. Adv Anim Vet Sci 3:58-70

Malinga M, Szefer P, Gabrielsen GW (2010) Age, sex and spatial dependent variations in heavy metals levels in the Glaucous Gulls (Larus hyperboreus) from the Bjørnøya and Jan Mayen, Arctic. Environ Monit Assess 169:407-416. https://doi.org/10.1007/s10661-009-1183-3

Malvandi H (2017) Preliminary evaluation of heavy metal contamination in the Zarrin-Gol River sediments, Iran. Mar Pollut Bull 117:547-553.

https://doi.org/10.1016/j.marpolbul.2017.02.035

Mansoori J (2008) A Guide to the Birds of Iran. Farzaneh Pub, Tehran

Mansouri B, Babaei H, Hoshyari E, et al (2012) Assessment of Trace-Metal Concentrations in Western Reef Heron (Egrettagularis) and Siberian Gull (Larusheuglini) From Southern Iran. Arch Environ Contam Toxicol 63:280-287

Mateo R, Guitart R (2003) Heavy Metals in Livers of Waterbirds from Spain. Arch Environ Contam Toxicol 44:398-404. https://doi.org/10.1007/s00244-0022040-3

Morris CM, Candy JM, Oakley AE, et al (1992) Histochemical distribution of non-haem iron in the human brain. Cells Tissues Organs 144:235-257

Nam D-H, Anan Y, Ikemoto T, Tanabe S (2005) Multielemental accumulation and its intracellular distribution in tissues of some aquatic birds. Mar Pollut Bull 50:1347-1362. https://doi.org/10.1016/j.marpolbul.2005.05.004

Nam D, Lee D (2006) Reproductive effects of heavy metal accumulation on breeding feral pigeons ( Columba livia ). 366:682-687. https://doi.org/10.1016/j.scitotenv.2006.02.004

Ohlendorf HM, Lowe RW, Kelly PR, Harvey TE (1986) Selenium and heavy metals in San Francisco Bay diving ducks. J Wildl Manage 64-70

Okati N (2013) Biomonitoring of heavy metals in birds in Iran in relation to trophic levels. Int Res J Appl Basic Sci 4:3478-3485

Outridge PM, Scheuhammer AM (1993) Bioaccumulation and toxicology of nickel: implications for wild mammals and birds. Environ Rev 1:172-197

Pain DJ (1996) Lead in waterfowl In Beyer WM, Heinz GH, Redman-Norwood AW., eds, Environmental Contaminants in Wildlife: Interpreting Tissue

Concentrations 
Parslow JLF, Thomas GJ, Williams TD (1982) Heavy metals in the livers of waterfowl from the ouse washes, England. Environ Pollut Ser A, Ecol Biol 29:317327. https://doi.org/10.1016/0143-1471(82)90070-8

Peakall D, Burger J (2003) Methodologies for assessing exposure to metals: speciation, bioavailability of metals, and ecological host factors. Ecotoxicol Environ Saf 56:110-121

Plaskett D, Potter IC (1979) Heavy metal concentrations in the muscle tissue of 12 species of teleost from Cockburn Sound, Western Australia. Mar Freshw Res 30:607-616

Plessl C, Jandrisits P, Krachler R, et al (2017) Heavy metals in the mallard Anas platyrhynchos from eastern Austria. Sci Total Environ 580:670-676. https://doi.org/10.1016/j.scitotenv.2016.12.013

Rajaei G, Mansouri B, Jahantigh H, Hamidian AH (2012) Metal Concentrations in the Water of Chah Nimeh Reservoirs in Zabol, Iran. Bull Environ Contam Toxicol 89:495-500. https://doi.org/10.1007/s00128-012-0738-0

Rice DC (1992) Behavioral effects of lead in monkeys tested during infancy and adulthood. Neurotoxicol Teratol 14:235-245

Savinov VM, Gabrielsen GW, Savinova TN (2003) Cadmium, zinc, copper, arsenic, selenium and mercury in seabirds from the Barents Sea: levels, inter-specific and geographical differences. Sci Total Environ 306:133-158. https://doi.org/10.1016/S0048-9697(02)00489-8

Sayadi MH, Rezaei MR, Ghaleno OR (2015) Natural and Concentration Factor Distribution of Heavy Metals in Sediments of Chah Nimeh Reservoirs of Sistan , Iran. 3:1003-1012

Scheuhammer AM (1987) The chronic toxicity of aluminium, cadmium, mercury, and lead in birds: a review. Environ Pollut 46:263-295

Sileo L, Nelson Beyer W, Mateo R (2003) Pancreatitis in wild zinc-poisoned waterfowl. Avian Pathol 32:655-660

Sinka-Karimi MH, Pourkhabbaz AR, Hassanpour M, Levengood JM (2015) Study on Metal Concentrations in Tissues of Mallard and Pochard from Two Major Wintering Sites in Southeastern Caspian Sea, Iran. Bull Environ Contam Toxicol 95:292-297. https://doi.org/10.1007/s00128-015-1591-8

Sinkakarimi MH, Pourkhabbaz AR, Hassanpour M (2013) The study of waterfowl organs as bioindicators of metals pollution in southeastern Caspian Sea [MSc Thesis]. Birjand, Iran: Department of Environment, University of Birjand. MSc thesis, Birjand University

Sinkakarimi MH, Pourkhabbaz AR, Hassanpour M, et al (2015a) Potential human health risk assessment of heavy metals in the flesh of mallard and pochard in the South Eastern Caspian Sea region of Iran. J Adv Environ Heal Res 3:139-145

Sinkakarimi MH, Solgi E, Hassanpour M, Levengood JM (2015b) Dietary Intake and Health Risk Assessment of Heavy Metals Consumption of Anas strepera and Anas crecca in Southeastern Caspian Sea. Podoces 9:54-59

Stewart FM, Phillips RA, Catry P, Furness RW (1995) Influence of species, age and diet on mercury concentrations in Shetland seabirds

Szefer P, Falandysz J (1986) Trace metals in the bones of scaup ducks (Aythya marila L.) wintering in Gdańsk Bay, Baltic Sea, 1982-1983 and 1983-1984. Sci Total Environ 53:193-199

Szefer P, Falandysz J (1987a) Trace metals in the soft tissues of scaup ducks (Aythya marila L.) wintering in Gdańsk bay, Baltic sea. Sci Total Environ 65:203-213. https://doi.org/10.1016/0048-9697(87)90173-2

Szefer P, Falandysz J (1987b) Trace metals in the soft tissues of scaup ducks (Aythya marila L.) wintering in Gdańsk Bay, Baltic Sea. Sci Total Environ $65: 203-213$

Taggart MA, Figuerola J, Green AJ, et al (2006) After the Aznalcóllar mine spill: Arsenic, zinc, selenium, lead and copper levels in the livers and bones of five waterfowl species. Environ Res 100:349-361. https://doi.org/10.1016/j.envres.2005.07.009

Taggart MA, Green AJ, Mateo R, et al (2009) Metal levels in the bones and livers of globally threatened marbled teal and white-headed duck from El Hondo, Spain. Ecotoxicol Environ Saf 72:1-9. https://doi.org/10.1016/j.ecoenv.2008.07.015

US EPA UEPA (2009) Risk-based concentration table. Philadelphia PA United States Environ Prot Agency, Washingt DC

US EPA UEPA (1989) Environmental Protection Agency. Assessing human health risks from chemically contaminated fish and shellfish: a guidance manual. Washington, DC: U.S. Environmental Protection Agenc. Office of Emergency and Remedial Response, US Environmental Protection Agency

USFDA (1993) Guidance documents for cadmium, chromium, lead and nickel. US Food Drug Adm Cent Food Saf Appl Nutr US Food Drug Adm Washington, DC

Vaneeden PH, Schoonbee HJ (1992) Concentration of Heavy metals in organs and tissues of the Redknobbed Coot. Ostrich 63:165-171

Wu X, Cobbina SJ, Mao G, et al (2016) A review of toxicity and mechanisms of individual and mixtures of heavy metals in the environment. Environ Sci Pollut Res 23:8244-8259

Page $11 / 15$ 
Zaccaroni A, Niccoli C, Andreani G, et al (2011) Trace metal concentration in wild avian species from Campania, Italy. Open Chem 9:86-93

Zamani-Ahmadmahmoodi R, Esmaili-Sari A, Savabieasfahani M, et al (2010) Mercury pollution in three species of waders from shadegan wetlands at the head of the persian gulf. Bull Environ Contam Toxicol 84:326-330. https://doi.org/10.1007/s00128-010-9933-z

Tables

Table 1 the concentrations of trace metals ( $\mu \mathrm{g} / \mathrm{kg} \mathrm{dw}$ ) in brain and liver, kidney, brain and muscle of waterfowl from the Chahnimeh of

\begin{tabular}{|c|c|c|c|c|c|c|c|c|c|c|c|c|c|c|c|c|}
\hline \multirow{2}{*}{\begin{tabular}{l}
\multicolumn{1}{c}{ goneh } \\
Common name / \\
Species
\end{tabular}} & & \multirow[b]{2}{*}{ Weight } & \multirow[b]{2}{*}{ Langhe } & \multicolumn{4}{|c|}{ Sistan } & \multicolumn{4}{|c|}{ Kidney } & \multicolumn{4}{|c|}{ Brain } & \multirow[b]{2}{*}{$\bar{Z}$} \\
\hline & & & & $\mathrm{Zn}$ & $\mathrm{Pb}$ & $\mathrm{Cd}$ & $\mathrm{Ni}$ & $\mathrm{Zn}$ & $\mathrm{Pb}$ & $\mathrm{Cd}$ & $\mathrm{Ni}$ & $\mathrm{Zn}$ & $\mathrm{Pb}$ & $\mathrm{Cd}$ & $\mathrm{Ni}$ & \\
\hline \multirow{4}{*}{$\begin{array}{l}\text { Cormorant (C) } \\
\text { (Phalacrocorax } \\
\text { carbo) } \\
\text { Number }=6\end{array}$} & Mean & 1.77 & 77.6 & 5.83 & 0.50 & 0.43 & 2.87 & 6.23 & 0.60 & 0.47 & 2.97 & 8.70 & 0.73 & 0.67 & 0.10 & 5 . \\
\hline & Median & 1.80 & 78.0 & 5.60 & 0.50 & 0.40 & 2.80 & 6.30 & 0.60 & 0.50 & 3.00 & 7.50 & 0.60 & 0.60 & 0.10 & 5. \\
\hline & Minimum & 1.70 & 75.0 & 5.50 & 0.50 & 0.40 & 2.70 & 5.80 & 0.50 & 0.40 & 2.70 & 6.90 & 0.60 & 0.50 & 0.10 & 5. \\
\hline & Maximum & 1.80 & 80.0 & 6.40 & 0.50 & 0.50 & 3.10 & 6.60 & 0.70 & 0.50 & 3.20 & 11.70 & 1.00 & 0.90 & 0.10 & 5. \\
\hline \multirow{4}{*}{$\begin{array}{l}\text { Great crested } \\
\text { grebe (G) } \\
\text { (Podiceps } \\
\text { cristatus) } \\
\text { Number }=10\end{array}$} & Mean & 860.6 & 50.0 & 7.62 & 0.66 & 0.60 & 3.66 & 21.54 & 1.78 & 1.54 & 10.54 & 27.88 & 2.12 & 2.08 & 0.24 & 7 \\
\hline & Median & 870.0 & 50.0 & 7.10 & 0.60 & 0.60 & 3.60 & 21.30 & 1.00 & 1.20 & 10.40 & 27.20 & 1.70 & 2.10 & 0.20 & 7. \\
\hline & Minimum & 799.0 & 47.0 & 5.10 & 0.30 & 0.40 & 2.50 & 6.90 & 0.70 & 0.50 & 3.30 & 19.70 & 1.10 & 1.50 & 0.20 & 6. \\
\hline & Maximum & 910.0 & 52.0 & 11.40 & 1.10 & 0.90 & 5.40 & 46.80 & 4.30 & 3.60 & 23.10 & 37.90 & 3.60 & 2.90 & 0.30 & 7. \\
\hline \multirow{3}{*}{$\begin{array}{l}\text { Shoveler (S) } \\
\text { (Anas } \\
\text { clypeata) } \\
\mathrm{n}=8\end{array}$} & Mean & 528.0 & 45.5 & 6.63 & 0.57 & 0.50 & 3.20 & 11.73 & 1.02 & 0.90 & 5.73 & 30.28 & 2.75 & 2.25 & 0.25 & 6 . \\
\hline & Median & 527.5 & 45.0 & 6.60 & 0.60 & 0.50 & 3.20 & 11.75 & 1.05 & 0.90 & 5.75 & 25.55 & 2.15 & 1.90 & 0.20 & 6. \\
\hline & Maximum & 557. & 50.0 & 7.30 & 0.60 & 0.50 & 3.40 & 15.10 & 1.40 & 1.20 & 7.50 & 47.40 & 4.60 & 3.50 & 0.40 & 7. \\
\hline \multirow{4}{*}{$\begin{array}{l}\text { Black-winged } \\
\text { Stilt (B) } \\
\text { (Himantopus } \\
\text { himantou) } \\
\text { Number }=10\end{array}$} & Mean & 180.40 & 38.6 & 52.32 & 4.70 & 3.94 & 25.50 & 59.72 & 5.60 & 4.64 & 32.92 & 39.06 & 3.44 & 2.92 & 0.36 & $\overline{6}$. \\
\hline & Median & 187.0 & 39.0 & 20.80 & 1.80 & 1.60 & 10.10 & 60.20 & 5.50 & 4.50 & 30.10 & 38.90 & 3.50 & 3.00 & 0.30 & 6. \\
\hline & Minimum & 146.0 & 35. & 17.10 & 1.50 & 1.20 & 8.00 & 20.20 & 2.00 & 1.00 & 20.80 & 31.40 & 2.70 & 2.30 & 0.30 & 6 \\
\hline & Maximum & 210.0 & 41.0 & 154.10 & 13.90 & 11.60 & 75.40 & 90.30 & 8.60 & 7.20 & 42.70 & 49.40 & 4.30 & 3.60 & 0.50 & 7. \\
\hline \multirow{4}{*}{$\begin{array}{l}\text { Marsh } \\
\text { Sandpiper (MS) } \\
\text { (Tringa } \\
\text { stagnatilis) } \\
\text { Number }=6\end{array}$} & Mean & 100.0 & 25.6 & 11.83 & 1.07 & .90 & 5.40 & 88.37 & 7.83 & 6.70 & 43.03 & 98.37 & 9.43 & 7.47 & 0.87 & 7. \\
\hline & Median & 100.0 & 26.0 & 12.20 & 1.10 & 1.00 & 5.90 & 98.40 & 8.70 & 7.50 & 47.70 & 113.50 & 10.90 & 8.60 & 1.00 & 7. \\
\hline & Minimum & 100.0 & 25.0 & 3.20 & .30 & .20 & 1.60 & 14.40 & 1.40 & 1.10 & 6.90 & 60.40 & 5.80 & 4.60 & 0.50 & 6. \\
\hline & Maximum & 100.0 & 26.0 & 20.10 & 1.80 & 1.50 & 8.70 & 152.30 & 13.40 & 11.50 & 74.50 & 121.20 & 11.60 & 9.20 & 1.10 & 7. \\
\hline Moorhen (M) & Mean & 253.3 & 28.3 & 15.60 & 1.23 & 1.20 & 7.57 & 98.97 & 8.73 & 7.47 & 47.37 & 62.53 & 3.50 & 4.73 & 0.53 & $\overline{8}$ \\
\hline (Gallinula & Median & 260.0 & 28.0 & 14.60 & 1.00 & 1.10 & 7.20 & 123.60 & 11.10 & 9.20 & 57.50 & 47.80 & 2.90 & 3.60 & 0.40 & 7. \\
\hline chloropus) & Minimum & 240.0 & 28.0 & 11.40 & 0.70 & 0.90 & 5.30 & 36.80 & 3.60 & 2.80 & 18.00 & 35.10 & 1.40 & 2.60 & 0.30 & 7. \\
\hline Northern & Mean & 150.0 & 27.0 & 2.10 & 2.10 & 2.0 & 1.60 & 58.30 & 5.30 & 4.50 & 28.70 & 61.20 & 5.50 & 4.70 & 0.50 & 7 \\
\hline lapwing (N) & Median & 150.0 & 27.0 & 2.10 & 2.10 & 2.0 & 1.60 & 58.30 & 5.30 & 4.50 & 28.70 & 61.20 & 5.50 & 4.70 & 0.50 & 7. \\
\hline $\begin{array}{l}\text { (vanemus } \\
\text { vanellus) }\end{array}$ & Minimum & 150.0 & 27.0 & 2.10 & 2.10 & 2.0 & 1.60 & 58.30 & 5.30 & 4.50 & 28.70 & 61.20 & 5.50 & 4.70 & 0.50 & 7. \\
\hline Number $=2$ & Maximum & 150.0 & 27.0 & 2.10 & 2.10 & 2.0 & 1.60 & 58.30 & 5.30 & 4.50 & 28.70 & 61.20 & 5.50 & 4.70 & 0.50 & 7. \\
\hline Eurasian & Mean & 1550.0 & 79.0 & 6.90 & 0.70 & 0.50 & 3.40 & 6.50 & 0.50 & 0.50 & 3.20 & 7.20 & 0.60 & 0.50 & 0.10 & 7. \\
\hline Spoonbill (E) & Median & 1550.0 & 79.0 & 6.90 & 0.70 & 0.50 & 3.40 & 6.50 & 0.50 & 0.50 & 3.20 & 7.20 & 0.60 & 0.50 & 0.10 & 7. \\
\hline leucorodia) & Minimum & 1550.0 & 79.0 & 6.90 & 0.70 & 0.50 & 3.40 & 6.50 & 0.50 & 0.50 & 3.20 & 7.20 & 0.60 & 0.50 & 0.10 & 7. \\
\hline Number $=2$ & Maximum & 1550.0 & 79.0 & 6.90 & 0.70 & 0.50 & 3.40 & 6.50 & 0.50 & 0.50 & 3.20 & 7.20 & 0.60 & 0.50 & 0.10 & 7. \\
\hline Total & Mean & 403.2 & 45.0 & 17.40 & 1.61 & 1.39 & 8.44 & 43.95 & 3.93 & 3.34 & 22.09 & 41.32 & 3.44 & 3.11 & 0.36 & 6 . \\
\hline number $=50$ & Median & 240.0 & 42.0 & 7.30 & 0.70 & 0.60 & 3.60 & 21.30 & 2.00 & 1.20 & 10.90 & 34.50 & 2.70 & 2.60 & 0.30 & 7. \\
\hline & Minimum & 1.7 & 25.0 & 2.10 & 0.30 & 0.20 & 1.60 & 5.80 & 0.50 & 0.40 & 2.70 & 6.90 & 0.60 & 0.50 & 0.10 & 5 \\
\hline & Maximum & 1550.0 & 80.0 & 154.10 & 13.90 & 11.60 & 75.40 & 152.30 & 13.40 & 11.50 & 74.50 & 121.20 & 11.60 & 9.20 & 1.10 & 10. \\
\hline
\end{tabular}

Table 2 the concentrations of trace metals $(\mu \mathrm{g} / \mathrm{kg} \mathrm{dw})$ in brain and liver, kidney, brain and muscle of waterfowl from the Chahnimeh of Sistan and effect habitat water fowl 


\begin{tabular}{|c|c|c|c|c|c|c|c|c|c|c|c|c|}
\hline & \multicolumn{4}{|c|}{ Liver } & \multicolumn{4}{|c|}{ Kidney } & \multicolumn{3}{|c|}{ Brain } \\
\hline & & \multirow{2}{*}{$\begin{array}{l}\mathrm{Zn} \\
6.95\end{array}$} & \multirow{2}{*}{$\begin{array}{l}\mathrm{Pb} \\
0.60\end{array}$} & \multirow{2}{*}{$\begin{array}{l}\mathrm{Cd} \\
0.54\end{array}$} & \multirow{2}{*}{$\begin{array}{l}\mathrm{Ni} \\
3.36\end{array}$} & \multirow{2}{*}{$\begin{array}{c}\mathrm{Zn} \\
15.80\end{array}$} & \multirow{2}{*}{$\begin{array}{l}\mathrm{Pb} \\
1.34\end{array}$} & \multirow{2}{*}{$\begin{array}{l}\mathrm{Cd} \\
1.14\end{array}$} & \multirow{2}{*}{$\begin{array}{l}\mathrm{Ni} \\
7.70\end{array}$} & \multirow{2}{*}{$\begin{array}{l}\mathrm{Zn} \\
20.69\end{array}$} & \multirow{2}{*}{$\begin{array}{l}\mathrm{Pb} \\
1.60\end{array}$} & \multirow{2}{*}{$\begin{array}{r}\mathrm{Cl}_{1} \\
1.5\end{array}$} \\
\hline Fish Mean & Feeding Habits & & & & & & & & & & & \\
\hline & $\begin{array}{ll}\text { ish } & \text { Mean } \\
\text { redator } & \text { Median }\end{array}$ & 6.70 & 0.55 & $\begin{array}{l}0.54 \\
0.50\end{array}$ & 3.15 & 8.70 & 0.80 & 0.65 & 4.15 & 22.50 & 1.35 & 1.6 \\
\hline \multirow{2}{*}{$\begin{array}{l}\text { Number }= \\
16\end{array}$} & Minimum & 5.10 & 0.30 & 0.40 & 2.50 & 5.80 & 0.50 & 0.40 & 2.70 & 6.90 & \multicolumn{2}{|l|}{.60} \\
\hline & Maxim & 11.40 & 1.10 & 0.90 & 5.40 & 46.80 & 4.30 & 3.60 & 23.10 & 37.90 & \multicolumn{2}{|l|}{3.60} \\
\hline \multirow{2}{*}{$\begin{array}{l}\text { Omnivores } \\
\text { Number }= \\
14\end{array}$} & & 10.4 & 0.86 & 0.80 & 5.07 & 49. & 4.33 & 3.7 & 23. & 44.10 & 3.07 & $3.3^{2}$ \\
\hline & Med & 7.30 & 0.60 & 0.50 & 3.40 & 15.10 & 1.40 & 1.20 & 7.50 & 35.10 & 2.20 & $2 . €$ \\
\hline \multirow{2}{*}{14} & & 6.00 & 0.50 & 0.50 & 3.00 & 8. & 0.60 & 0.60 & 3.90 & 22.60 & 1.40 & 1.7 \\
\hline & $\mathrm{Ma}$ & 20.80 & 2.00 & 1.60 & 10.20 & 136.50 & 11.50 & 10.40 & 66.60 & 104.70 & 6.20 & $8 . C$ \\
\hline \multirow{4}{*}{$\begin{array}{l}\text { Invertebrate } \\
\text { predator } \\
\text { Number = } \\
18\end{array}$} & Mean & 33.24 & 3.20 & 2.71 & 16.14 & 69.11 & 6.31 & 5.31 & 35.82 & 61.29 & 5.67 & 4.6 \\
\hline & Median & $18.20 *$ & $1.80 *$ & $1.50 *$ & 8.70* & $60.20 *$ & $5.50 *$ & $4.50 *$ & $30.10 *$ & $49.40 *$ & 4.30 & 3.6 \\
\hline & Min & 2.10 & 0.30 & 0.20 & 1.60 & & 1.40 & 1. & & 31.40 & 2.70 & 2.3 \\
\hline & Max & 54.10 & 13.90 & 11.60 & 75.40 & 52.30 & 13.40 & 11.50 & 74.50 & 121.20 & 11.60 & 9.2 \\
\hline \multirow{4}{*}{$\begin{array}{l}\text { Fish and } \\
\text { crab } \\
\text { predator } \\
\text { Number = } 2\end{array}$} & Mean & 6.90 & 0.70 & 0.50 & 3.40 & 6.50 & 0.50 & 0.50 & 3.20 & 7.20 & 0.60 & 0.5 \\
\hline & Med & 6.90 & 0.70 & 0.50 & 3.40 & 6.5 & 0.50 & 0.50 & 3.20 & 7.20 & 0.60 & 0.5 \\
\hline & & 6.90 & 0.70 & 0.50 & 3.40 & 6. & 0.50 & 0.50 & 3.20 & 7.20 & 0.60 & 0.5 \\
\hline & Maximum & 6.90 & 0.70 & 0.50 & 3.40 & 6.50 & 0.50 & 0.50 & 3.20 & 7.20 & 0.60 & 0.5 \\
\hline
\end{tabular}

$$
*=P<0.05
$$

Table 3 the concentrations of trace metals $(\mu \mathrm{g} / \mathrm{kg} \mathrm{dw})$ in brain and liver, kidney, brain and muscle of waterfowl from the Chahnimeh of Sistan and effect migration water fowl

\begin{tabular}{|c|c|c|c|c|c|c|c|c|c|c|c|c|c|c|}
\hline & & \multicolumn{4}{|c|}{ Liver } & \multicolumn{4}{|c|}{ Kidney } & \multicolumn{4}{|c|}{ Brain } & \\
\hline & & $\mathrm{Zn}$ & $\mathrm{Pb}$ & $\mathrm{Cd}$ & $\mathrm{Ni}$ & $\mathrm{Zn}$ & $\mathrm{Pb}$ & $\mathrm{Cd}$ & $\mathrm{Ni}$ & $\mathrm{Zn}$ & $\mathrm{Pb}$ & $\mathrm{Cd}$ & $\mathrm{Ni}$ & \\
\hline Long-distance & Mean & 7.45 & 0.77 & 0.68 & 3.58 & 29.60 & 2.59 & 2.22 & 14.44 & 38.24 & 3.42 & 2.88 & 0.34 & \\
\hline migrants & Median & 6.90 & 0.60 & 0.50 & 3.20 & 12.30 & 1.00 & 0.90 & 5.90 & 26.70 & 2.10 & 2.00 & 0.20 & \\
\hline$(\mathrm{C}, \mathrm{G}, \mathrm{S}, \mathrm{MS}, \mathrm{N}, \mathrm{E})$ & Minimum & 2.10 & 0.30 & 0.20 & 1.60 & 5.80 & 0.50 & 0.40 & 2.70 & 6.90 & 0.60 & 0.50 & 0.10 & \\
\hline Number = 34 & Maximum & 20.10 & 2.10 & 2.00 & 8.70 & 152.30 & 13.40 & 11.50 & 74.50 & 121.20 & 11.60 & 9.20 & 1.10 & \\
\hline Local & Mean & 38.55* & 3.40* & 2.91* & 18.77* & $74.44 *$ & 6.78* & $5.70 *$ & $38.34 *$ & 47.86 & 3.46 & 3.60 & 0.43 & \\
\hline migration & Median & 19.50 & 1.75 & 1.50 & 9.45 & 72.75 & 6.75 & 5.85 & 35.60 & 40.00 & 3.20 & 3.05 & 0.35 & \\
\hline$(\mathrm{B}, \mathrm{M})$ & Minimum & 11.40 & 0.70 & 0.90 & 5.30 & 20.20 & 2.00 & 1.00 & 18.00 & 31.40 & 1.40 & 2.30 & 0.30 & \\
\hline Number $=16$ & Maximum & 154.10 & 13.90 & 11.60 & 75.40 & 136.50 & 11.50 & 10.40 & 66.60 & 104.70 & 6.20 & 8.00 & 0.90 & 1 \\
\hline
\end{tabular}

$*=P<0.05$

Table 4: Estimated daily and weekly metal intakes (or $\mu \mathrm{g} /$ day w wt, $\mu \mathrm{g} /$ week) for Sistan population consuming edibles parts birds of Chahnimeh from Sistan (Iran). 


\begin{tabular}{|c|c|c|c|c|c|c|c|c|c|c|c|c|c|c|c|c|c|}
\hline & & \multicolumn{4}{|c|}{$\mathrm{Zn}$} & \multicolumn{4}{|c|}{$\mathrm{Pb}$} & \multicolumn{4}{|c|}{$\mathrm{Cd}$} & \multicolumn{4}{|c|}{$\mathrm{Ni}$} \\
\hline PTWI & & \multicolumn{4}{|c|}{7000} & \multicolumn{4}{|c|}{25} & \multicolumn{4}{|c|}{7} & \multicolumn{4}{|c|}{35} \\
\hline PTWI70 & & \multicolumn{4}{|c|}{490000} & \multicolumn{4}{|c|}{1750} & \multicolumn{4}{|c|}{490} & \multicolumn{4}{|c|}{2450} \\
\hline PTDI & & \multicolumn{4}{|c|}{70000} & \multicolumn{4}{|c|}{250} & \multicolumn{4}{|c|}{70} & \multicolumn{4}{|c|}{350} \\
\hline & & Kidney & Liver & muscle & Total & Kidney & Liver & muscle & Total & Kidney & Liver & muscle & Total & Kidney & Liver & muscle & Total \\
\hline Cormorant (C) & EDI & 5.9 & 5.5 & 24.2 & 35.6 & 0.5 & 0.5 & 1.3 & 2.3 & 0.5 & 0.4 & 1.9 & 2.7 & 2.8 & 2.7 & 11.6 & 17.2 \\
\hline & EWI & 41.4 & 38.8 & 178.0 & 258.3 & 3.8 & 3.3 & 9.8 & 16.9 & 3.2 & 3.0 & 13.7 & 19.8 & 19.9 & 19.1 & 85.3 & 124.4 \\
\hline \multirow{2}{*}{$\begin{array}{r}\text { Great crested grebe } \\
\text { (G) }\end{array}$} & EDI & 20.5 & 7.3 & 32.0 & 59.7 & 1.7 & 0.6 & 3.2 & 5.5 & 1.5 & 0.6 & 2.5 & 4.5 & 10.0 & 3.5 & 15.6 & 29.1 \\
\hline & EWI & 143.7 & 50.8 & 235.4 & 429.9 & 11.9 & 4.4 & 23.3 & 39.6 & 10.4 & 3.9 & 18.1 & 32.3 & 70.3 & 24.3 & 114.7 & 209.3 \\
\hline \multirow[t]{2}{*}{ Shoveler (S) } & EDI & 11.2 & 6.3 & 28.7 & 46.2 & 1.0 & 0.6 & 2.4 & 4.0 & 0.9 & 0.5 & 2.2 & 3.5 & 5.5 & 3.1 & 13.6 & 22.1 \\
\hline & EWI & 78.3 & 44.3 & 211.1 & 333.7 & 7.0 & 3.9 & 17.9 & 28.8 & 6.0 & 3.3 & 16.3 & 25.7 & 38.2 & 21.4 & 100.3 & 159.9 \\
\hline \multirow[t]{2}{*}{ Black-winged Stilt (B) } & EDI & 56.9 & 49.8 & 31.4 & 138.1 & 5.3 & 4.5 & 2.6 & 12.5 & 4.4 & 3.8 & 2.4 & 10.5 & 31.4 & 24.3 & 15.0 & 70.6 \\
\hline & EWI & 398.2 & 348.8 & 231.4 & 978.4 & 37.3 & 31.4 & 19.5 & 88.2 & 30.9 & 26.3 & 17.5 & 74.7 & 219.6 & 169.9 & 110.2 & 499.7 \\
\hline \multirow{2}{*}{$\begin{array}{l}\text { Marsh } \\
\text { Sandpiper (MS) }\end{array}$} & EDI & 84.1 & 11.3 & 32.7 & 128.1 & 7.5 & 1.0 & 2.8 & 11.3 & 6.4 & 0.9 & 2.5 & 9.8 & 41.0 & 5.1 & 15.9 & 62.1 \\
\hline & EWI & 589.0 & 79.0 & 240.7 & 908.7 & 52.2 & 7.2 & 21.0 & 80.4 & 44.8 & 6.0 & 18.5 & 69.2 & 287.0 & 35.9 & 117.5 & 440.3 \\
\hline \multirow[t]{2}{*}{ Moorhen (M) } & EDI & 94.2 & 14.8 & 37.5 & 146.6 & 8.3 & 1.2 & 3.4 & 12.9 & 7.1 & 1.1 & 2.9 & 11.2 & 45.1 & 7.2 & 18.2 & 70.5 \\
\hline & EWI & 534.6 & 107.2 & 276.5 & 918.3 & 50.5 & 9.2 & 25 & 84.6 & 40.1 & 8.2 & 21.5 & 69.8 & 251.5 & 51.5 & 134.3 & 437.2 \\
\hline \multirow{2}{*}{$\begin{array}{l}\text { Northern } \\
\text { lapwing }(\mathrm{N})\end{array}$} & EDI & 55.5 & 2.0 & 33.4 & 90.9 & 5.1 & 1.9 & 2.7 & 9.6 & 4.3 & 1.5 & 2.6 & 8.4 & 27.3 & 9.1 & 16.1 & 52.5 \\
\hline & EWI & 388.4 & 13.8 & 246.2 & 648.3 & 35.4 & 13.2 & 19.7 & 68.3 & 29.9 & 10.5 & 19.1 & 59.5 & 191.1 & 64.0 & 118.6 & 373.7 \\
\hline \multirow{2}{*}{$\begin{array}{l}\text { Eurasian Spoonbill } \\
\text { (E) }\end{array}$} & EDI & 6.2 & 6.5 & 33.1 & 45.8 & 0.5 & 0.6 & 3.1 & 4.3 & 0.5 & 0.5 & 2.5 & 3.5 & 3.1 & 3.2 & 15.5 & 21.8 \\
\hline & EWI & 43.3 & 45.7 & 243.6 & 332.6 & 3.4 & 4.5 & 23.1 & 31.0 & 3.4 & 3.5 & 18.8 & 25.6 & 21.5 & 22.6 & 114.1 & 158.2 \\
\hline
\end{tabular}

\section{Figures}

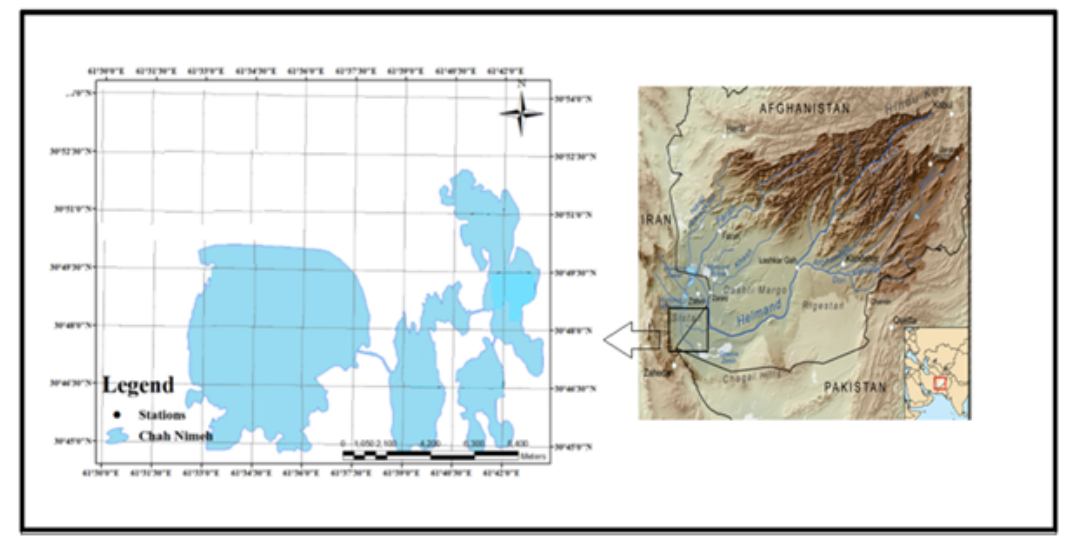

Figure 1

Location map of study area. Note: The designations employed and the presentation of the material on this map do not imply the expression of any opinion whatsoever on the part of Research Square concerning the legal status of any country, territory, city or area or of its authorities, or concerning the delimitation of its frontiers or boundaries. This map has been provided by the authors.

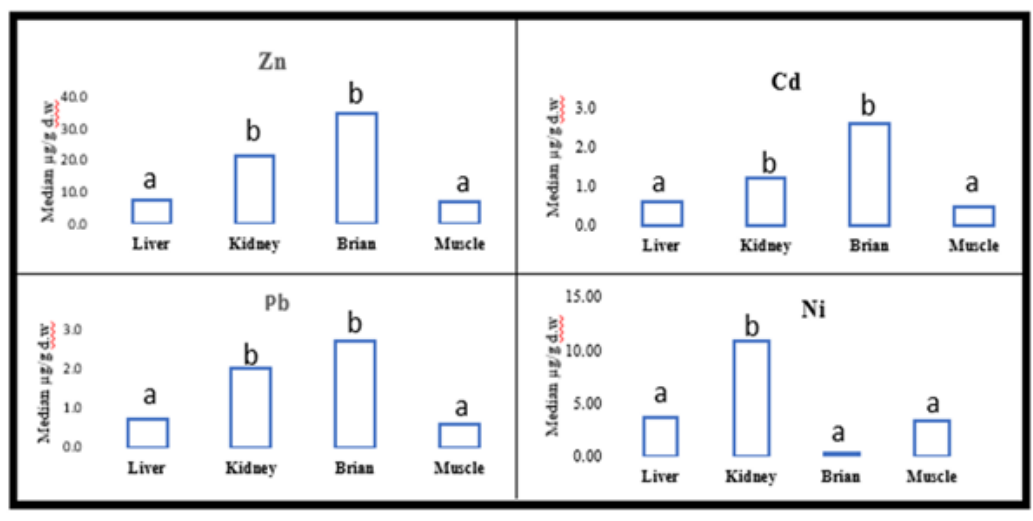

Figure 2 
Median concentration $\mu \mathrm{g} / \mathrm{g}$ d. $\mathrm{w}$ in difference tissues birds.

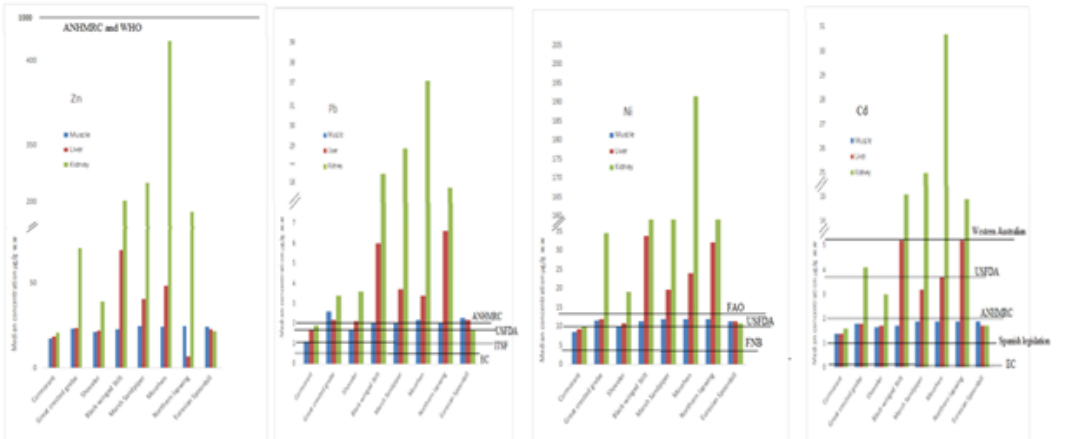

Figure 3

Median concentration heavy metal and compare with US Food and Drug Administration (USFDA), Australian National Health and Medical Research Council (ANHMRC), Turkish Standards for Food (ITSF), European Commission (EC), Food and Nutrition Board (FNB), Food and Agriculture Organization (FAO) and World Health Organization
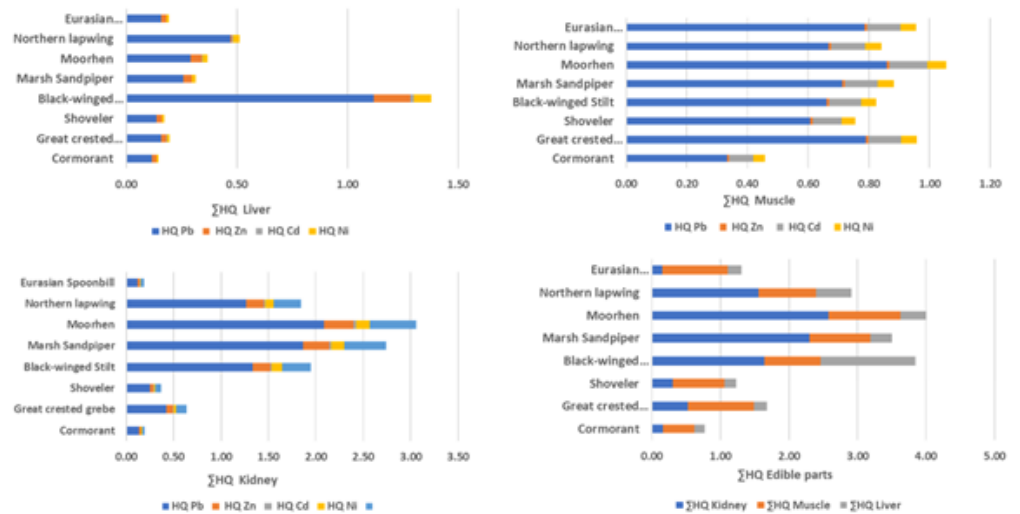

\section{Figure 4}

Estimated potential health risks for $\mathrm{Zn}, \mathrm{Pb}, \mathrm{Cd}$, and $\mathrm{Ni}$ via consumption liver, kidney, muscles and collected them (edible parts). Hazard quotients (HQ) $\Sigma \mathrm{HQ} H \mathrm{H}$ $\mathrm{Pb}+\mathrm{HQ} \mathrm{Cd}+\mathrm{HQ}+\mathrm{HQ} \mathrm{NI}+\mathrm{HQ} \mathrm{Zn}$ 